\title{
molecules
}

ISSN 1420-3049

www.mdpi.com/journal/molecules

Article

\section{A Practical Route for the Preparation of 1,4,7-Triazacyclononanyl Diacetates with a Hydroxypyridinonate Pendant Arm}

\section{Yongkang Gai, Zhongping Hu, Zhao Rong, Xiang Ma * and Guangya Xiang *}

School of Pharmacy, Tongji Medical College, Huazhong University of Science and Technology, Wuhan 430030, China; E-Mails: gykmail@gmail.com (Y.G.); maxwellsg@163.com (Z.H.); wojiaorz@gmail.com (Z.R.)

* Authors to whom correspondence should be addressed; E-Mails: xiangma@hust.edu.cn (X.M.); youjiti@mails.tjmu.edu.cn (G.X.); Tel.: +86-27-8369-2793 (X.M. \& G.X.);

Fax: +86-27-8369-2762 (X.M. \& G.X.).

Academic Editor: Roman Dembinski

Received: 2 September 2015 / Accepted: 16 October 2015 / Published: 23 October 2015

\begin{abstract}
The preparation of triazamacrocyclic hydroxypyridinonate (HOPO-TACN) derivatives as potential chelators for metals in biomedical applications was reported. The synthesis is based on a convergent synthetic approach, in which the key intermediate di-tert-butyl-2,2'-(1,4,7-triazonane-1,4-diyl) diacetate was coupled with a hydroxypyridinonate pendant arm. The method is suitable for rapid syntheses of metal chelator HOPO-TACNs of biomedical interest.
\end{abstract}

Keywords: 1,4,7-triazonane; hydroxypyridinonate; metal chelator

\section{Introduction}

There has been considerable interest in the synthesis and coordination chemistry of polyazacycles with coordinating pendant arms because of their potential use in applications such as magnetic resonance imaging (MRI) contrast agents [1,2], positron emission tomography (PET) [3,4], luminescence probes [5-8], catalysis [9], and so on. Among the polyazacycle derivatives, tetraazamacrocycles with acetate side chains have received the most attention owing to their strong chelating properties and higher selectivity toward di- or trivalent metal ions [10-13]. In contrast to tetraazamacrocycles, less attention has be paid 
on the triazamacrocycle derivatives [12,14-21]. The interest in the triazamacrocycle derivatives, especially 1,4,7-triazacyclononane (TACN) and TACN-based derivatives, has continued to grow in the past few years in the field of nuclear medicine for diagnosis and therapy [4,22-24].

TACN derivatives provide versatile platforms for strongly chelating radiometals such as ${ }^{90} \mathrm{Y},{ }^{177} \mathrm{Lu}$, ${ }^{212 / 213} \mathrm{Bi},{ }^{67 / 68} \mathrm{Ga},{ }^{64 / 67} \mathrm{Cu},{ }^{99 m} \mathrm{Tc}$ and ${ }^{18} \mathrm{~F}-\mathrm{Al}$ for SPECT, PET imaging and radiotherapy applications [25,26]. The strong coordination capabilities and high selectivity of the TACN derivatives toward di- or trivalent metal ions were determined by the cooperative binding mode from TACN and pendant arms. The pendent arm on TACN platform is expected to accelerate complexation with isotopes while maintaining a high level of stability of the complexes, coupled with the preorganization and macrocyclic effect of the TACN substructure [27]. So far, some researchers have been focused on the TACN derivatives with acetate pendant arms and phosphinate pendant arms. However, far less attention had been paid to other suitable pendent donor groups. In addition, selecting the correct type of chelating unit is one of the most decisive factors in achieving high selectivity toward the specific metal ion.

A class of multidentate hydroxypyridinonate (HOPO) was synthesized and studied for their outstanding abilities to scavenge lanthanide and actinide ions [28]. In particular, the octadentate ligand 3,4,3-LI(1,2-HOPO) has been identified as an effective metal chelator and is currently undergoing development as a prospective therapeutic actinide decorporation agent [29]. The pendent oxygencontaining donor hydroxypyridinonate demonstrated high affinities to hard Lewis acid.

In this context, new prospects for the synthesis of new chelating agents may be delineated while combining geometric and functional features of the TACN platform and the structural potential of common oxygen-containing donor, such as HOPO, and carboxylic acid. A triazamacrocycle with one HOPO and two carboxylic acids is ideally suited to form seven-coordinate complexes with two groups of facial donor, where the macrocyclic nitrogen atoms on the one side and the pendant donors on the other. The lanthanide ions and many other metal ions have coordination numbers larger than six, thus, these ligands have the potential to be excellent chelating agent in the MRI or radioimmunotherapy (RIT) applications.

With the aim of expanding the diversity of TACN based chelators which may permit orientation for all donors to assume an optimal geometry with coordination sphere, we explored the synthesis of HOPO-TACN derivatives, 2,2'-(7-(2-(3-hydroxy-2-oxopyridin-1(2H)-yl)ethyl)-1,4,7-triazonane-1,4-diyl) diacetic acid (1, HE-NO2A) and 2,2'-(7-(3-(3-hydroxy-2-oxopyridin-1(2H)-yl)propyl)-1,4,7-triazonane1,4-diyl) diacetic acid (2, HP-NO2A) as potential chelators for metal in the biomedical applications (Figure 1).

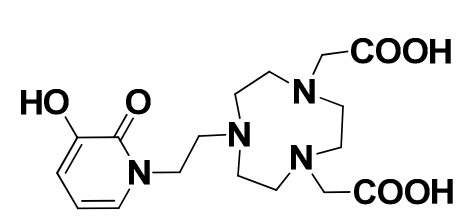

1, HE-NO2A
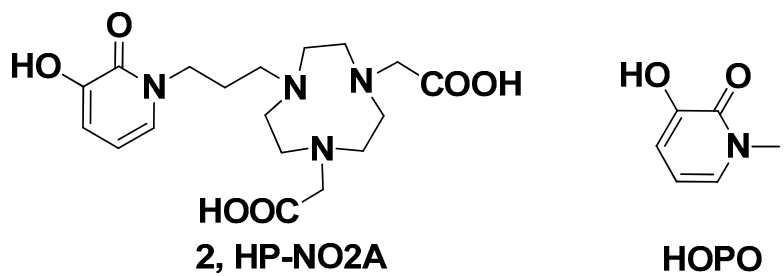

Figure 1. Structures of novel ligands HE-NO2A, HP-NO2A. 


\section{Results and Discussion}

The synthetic strategy for the preparation of the target ligands HE-NO2A and HP-NO2A involves the synthesis and coupling reaction of the fragment $\mathbf{3}$ with $\mathbf{4}$ or $\mathbf{5}$, which were obtained from readily available starting materials 1,4,7-triazacyclononane (TACN) and 3,2-hydroxypridinone (3,2-HOPO), respectively. The practical, reproducible, and readily scalable synthetic route and efficient purification of all precursor molecules for macrocyclic HOPO-TACN derivatives was developed as shown in Scheme 1.

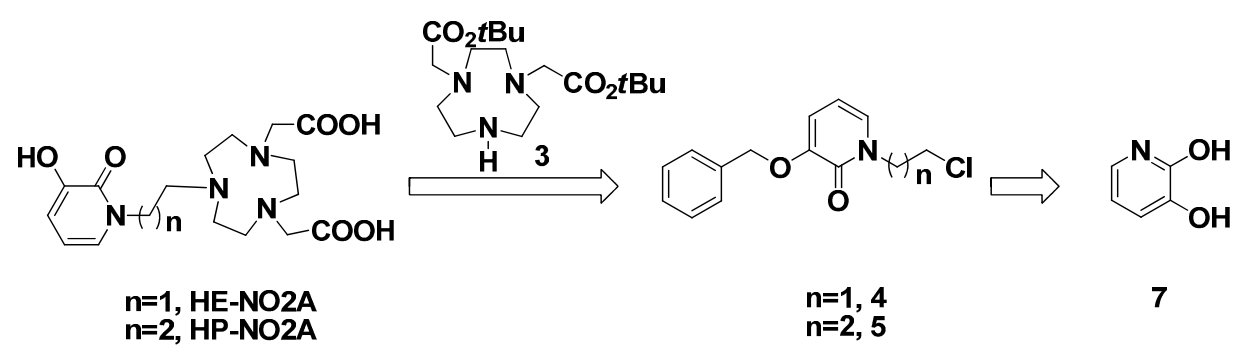

Scheme 1. Retrosynthetic route to HE-NO2A and HP-NO2A.

Fragment 3 were synthesized from 1,4,7-triazacyclononane (6) by reacting with tert-butylbromoacetate using the reported methods (Scheme 2) [24,30-32]. However, the yield was not good, because the reaction produced a mixture of mono-, di-, and trisubstituted TACN. We then optimized the reaction conditions by choosing a different solvent, optimizing the amount and ratio of reactants, and adding base to scavenge the protons formed during the reaction. In many attempts, we found that adding bases such as potassium carbonate, TEA, or sodium bicarbonate to the reaction negatively affected the yield of disubstituted compounds. The possible reason was that the protons produced in-situ would react with the unsubstituted amine to prevent oversubstitution to give trisubstituted compounds. In addition, through optimizing the ratio of reactants, the best yield was obtained when 2.0 eq. of tert-butylbromoacetate to TACN was used in the reaction. Finally, using acetonitrile as a solvent to alkylate TACN with 2 eq. tert-butyl bromoacetate gave as the major product disubstituted TACN in an acceptable yield as monitored by TLC. While the purification using column chromatography was unsuccessful, a carefully $\mathrm{pH}$-controlled extraction was applied to obtain the fragment 3 in 49\% isolated yield.
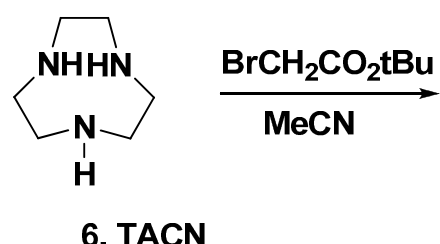

, TACN

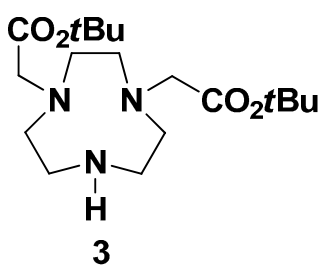

Scheme 2. Synthesis of fragment 3.

As shown in Scheme 3, the synthesis of fragment 4 was started from 3,2-hydroxypridinone, which was refluxed with 5 eq. ethyl bromoacetate under the protection of $\mathrm{N}_{2}$ to give 8 in $86 \%$ yield. In order to get the pure alcohol 10, the needed 9a was obtained via the hydroxyl function protection of $\mathbf{8}$ by $O$-benzylation. However, column chromatography must be applied to purify both 9a and 10. In another approach, 9b was directly obtained by $O$-benzylation and hydrolysis in one batch, and the purification by 
recrystallization proved very convenient. The following reduction of carboxylic acid $\mathbf{9 b}$ with $\mathrm{BH}_{3} / \mathrm{THF}$ was easily carried out to afforf $\mathbf{1 0}$ in higher yield than the approach from $\mathbf{9 a}$. When we tried to convert alcohol 10 into 10-OMs by treating it with 1.2 eq. of $\mathrm{MsCl}$ in chloroform in the presence of 3 eq. of TEA, an unexpected chloride $\mathbf{4}$ was obtained. The same product was obtained by treating $\mathbf{1 0}$ with $\mathrm{TsCl}$ [33]. During the above reaction, two new spots were formed visualized by TLC during the first few hours, which cannot be separated from the reaction mixture. We presumed that the unidentified spot was the intermediate 10-OMs. This spot was slowly converted into the other, and the whole reaction proceeded efficiently to give the chloride 4 in one batch in 72\% yield. With chloride $\mathbf{4}$ in hand, HE-NO2A (1) was prepared readily from disubstituted TACN 3 in two steps (Scheme 3). The alkylation of disubstituted TACN 3 with 4 using DIEA in refluxing MeCN gave the trisubstituted TACN 11 in excellent yield. Further reaction of $\mathbf{1 1}$ with the hydrolysis agent $\mathrm{HBr} / \mathrm{HOAc}$ at room temperature gave the target ligand 1 in $91 \%$ yield, where the $O$-benzyl hydroxyl protection functional group was simultaneously removed in the reaction.
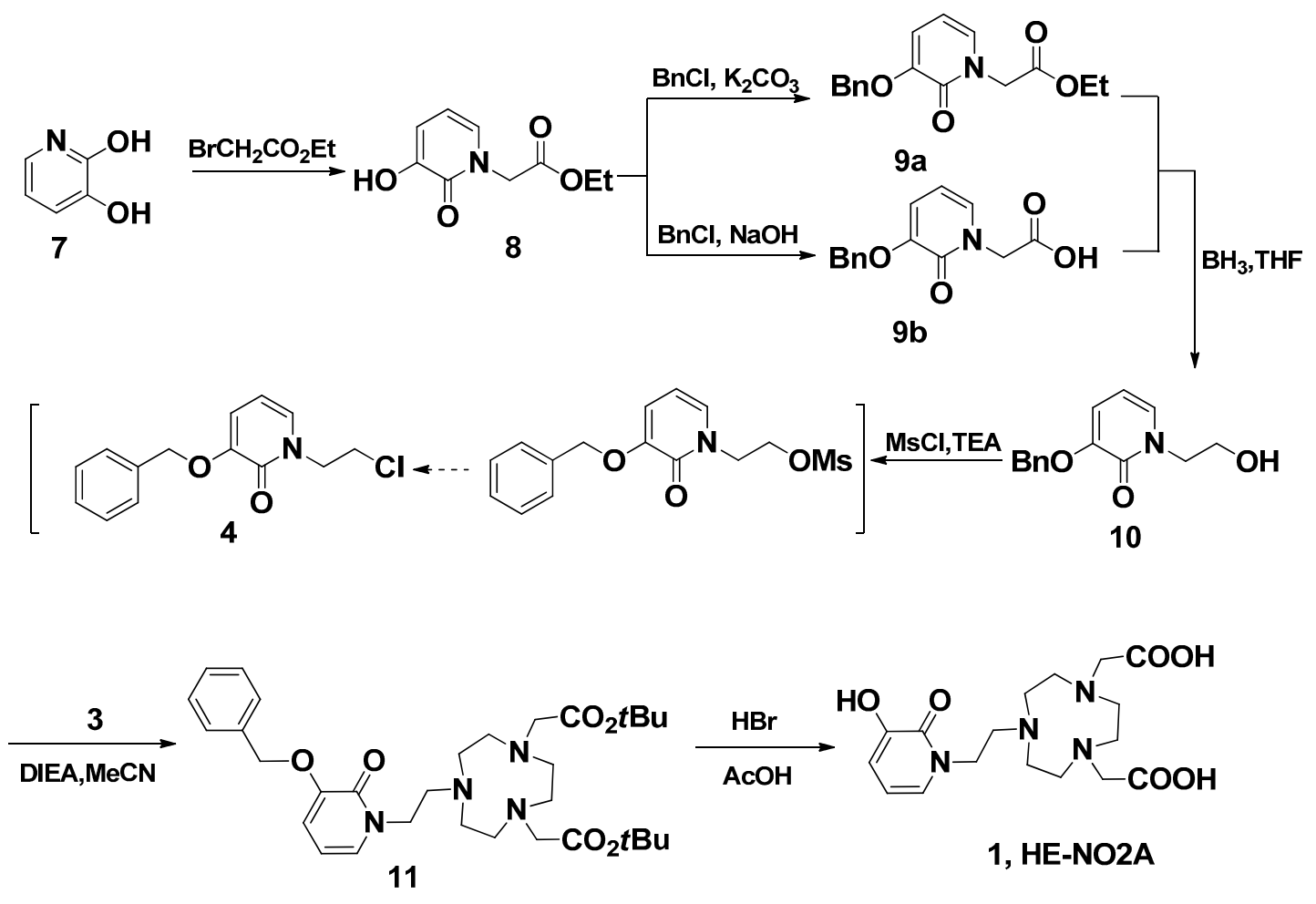

Scheme 3. The synthesis of ligand HE-NO2A (1).

Similar reaction strategy was applied in the synthesis of HP-NO2A (2), since the analogue $\mathbf{2}$ is just a one carbon extension on the HOPO side arm of 1 (Scheme 4). A Michael addition of methyl acrylate using $\mathrm{CsF}$ as a catalyst was employed to introduce a propanoic acid methyl ester side chain on 3,2-HOPO (7). The obtained product 12 was reacted with benzyl chloride in a $\mathrm{NaOH} / \mathrm{MeOH} / \mathrm{H}_{2} \mathrm{O}$ system to form $O$-benzyl protected 13a in $97 \%$ yield after a recrystallization from methanol. The reduction of 13a using borane-tetrahydrofuran at room temperature obtained 14 in $67 \%$ isolated yield. In order to improve the yield, the 14 could also be obtained through the reduction of $\mathbf{1 3 b}$ using borane-tetrahydrofuran at room temperature in $81 \%$ yield, after hydrolysis of 13a. This reduction method was successful in the preparation of $\mathbf{1 4}$ on a larger scale because of the higher yield and easier purification. Following the 
same conditions used for the synthesis of $\mathbf{4}$, alcohol $\mathbf{1 4}$ was treated with methanesulfonic chloride in chloroform in the presence of trimethylamine. However, the unusual 3,4-dihydro-2H-pyrido[2,1-b] [1,3] oxazin-5-ium product 15 was isolated. A similar reaction was also reported in another paper [34]. In another report, the electrophilic 3,2-HOPO imidate salt 15, which can be used for the facile incorporation of the HOPO moiety, reacted with a variety of nucleophiles, including amines [35]. Thus, in the current reaction, alkylation of $\mathbf{3}$ with $\mathbf{1 5}$ in acetonitrile in the presence of DIEA produced 16. After purification via column chromatography, pure 16 were obtained in 53\% yield. The tert-butyl and benzyl groups of 16 were then removed with $\mathrm{HBr} / \mathrm{AcOH}$ to obtain the target compounds HP-NO2A (2) in 90\% yield.

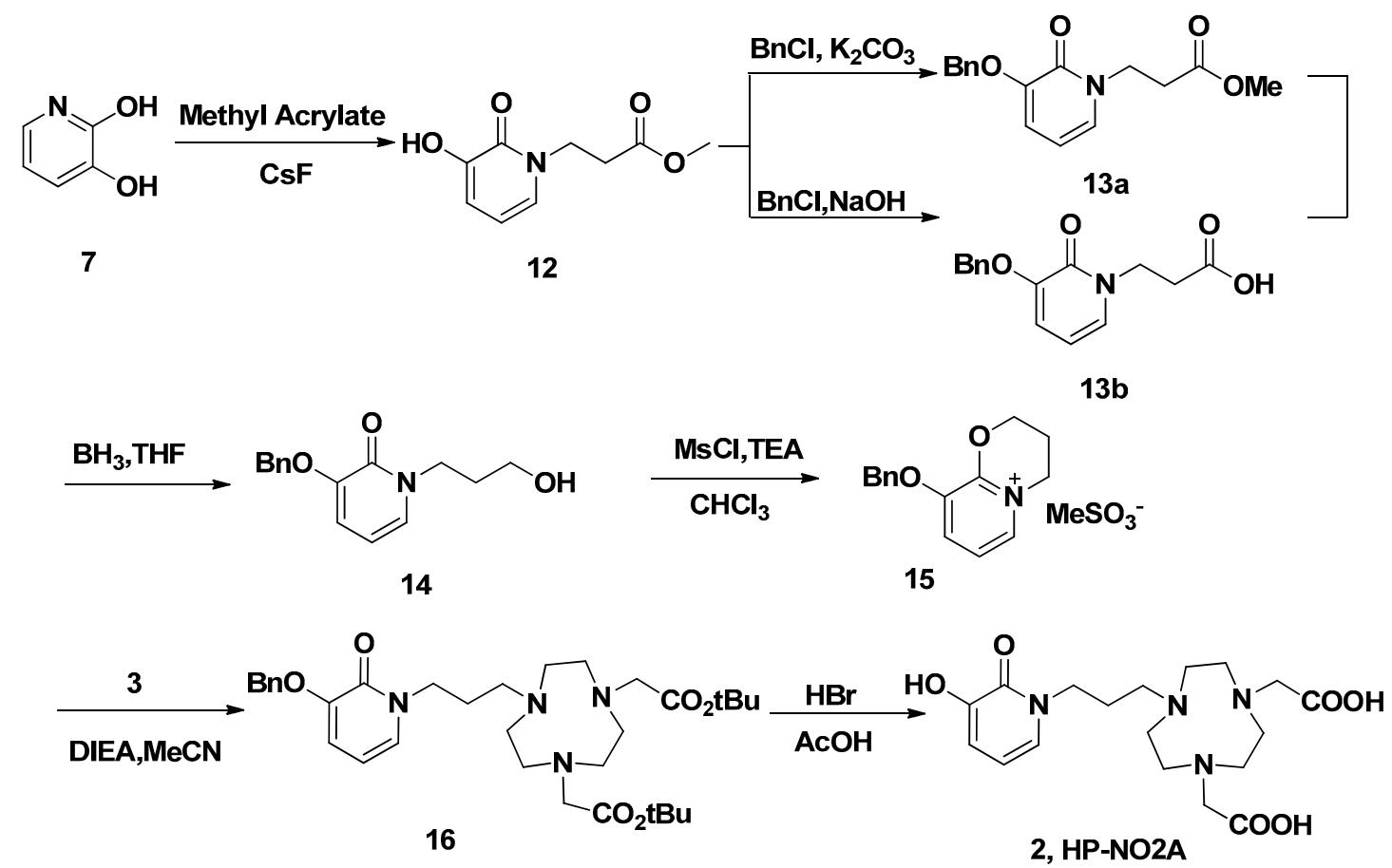

Scheme 4. The synthesis of ligand HP-NO2A (2).

In conclusion, efficient synthetic routes for two hydroxylpyridinone TACN derivatives have been developed. The new family of monosubstituted macrocyclic ligand HE-NO2A and HP-NO2A with 3,2-HOPO moieties as pendant arms could be used as potential metal chelators in future MRI or PET research. Future study for the ligands in making new $\mathrm{Ln}(\mathrm{III})$ complexes $\left(\mathrm{Gd}^{3+}, \mathrm{Eu}^{3+}, \mathrm{Tb}^{3+}, \mathrm{Yb}^{3+}\right)$ and other metal complexes $\left(\mathrm{Cu}^{2+}, \mathrm{Fe}^{3+}, \mathrm{Ga}^{3+}\right)$ is in progress.

\section{Experimental Section}

\subsection{General Information}

${ }^{1} \mathrm{H}-(400 \mathrm{MHz})$ and ${ }^{13} \mathrm{C}-\mathrm{NMR}(101 \mathrm{MHz})$ were obtained using a $400 \mathrm{MHz}$ WB Solid-State NMR Spectrometer (Bruker Corporation, Billerica, MA, USA), and chemical shifts are reported in ppm on the $\delta$ scale relative to TMS. High-resolution mass spectra (HRMS) were obtained on Bruker ultrafleXtreme MALDI-TOF/TOF matrix:HCCA (Bruker Corporation). 1,4,7-Triazacyclononane was purchased from Synpartner PharmaTech (Quzhou, China). 3,2-Hydroxypridinone was purchased from Aladdin Industrial 
(Shanghai, China). The other solvents and reagents were obtained from Sinopharm (Shanghai, China). All commercially available reagents were used as received.

\subsection{1,4-bis(tert-Butoxycarbonylmethyl)-1,4,7-triazacyclononane (3)}

To a solution of TACN $(3.0 \mathrm{~g}, 23 \mathrm{mmol})$ in $\mathrm{CH}_{3} \mathrm{CN}(50 \mathrm{~mL})$ at $0{ }^{\circ} \mathrm{C}$-butyl bromoacetate $(9.0 \mathrm{~g}$, $46 \mathrm{mmol})$ in $\mathrm{CH}_{3} \mathrm{CN}(100 \mathrm{~mL})$ was added dropwise over $4 \mathrm{~h}$. The resulting mixture was allowed to reach room temperature and stirred for $24 \mathrm{~h}$. The reaction mixture was filtered, the filtrate was evaporated, and the residue was treated with DI water $(15 \mathrm{~mL})$. The resulting solution was adjusted to $\mathrm{pH} 3 \mathrm{using}$ $1 \mathrm{M} \mathrm{HCl}$ and extracted with ether $(3 \times 50 \mathrm{~mL})$. The aqueous layer was then adjusted to $\mathrm{pH} 8$ using $1 \mathrm{M}$ $\mathrm{NaOH}$ and extracted with $\mathrm{CH}_{2} \mathrm{Cl}_{2}$. The $\mathrm{CH}_{2} \mathrm{Cl}_{2}$ layer was dried, filtered and evaporated to dryness. The residue was treated with ether $(50 \mathrm{~mL})$, and the yellowish solid formed and filtered. The solid was treated with hexane $(30 \mathrm{~mL})$ and filtered and dried to afford pure $3(4.0 \mathrm{~g}, 49 \%)$ as a white powder. ${ }^{1} \mathrm{H}-\mathrm{NMR}\left(\mathrm{CDCl}_{3}\right) \delta 3.36(\mathrm{~s}, 4 \mathrm{H}), 3.22(\mathrm{t}, J=5.6 \mathrm{~Hz}, 4 \mathrm{H}), 3.04(\mathrm{t}, J=5.7 \mathrm{~Hz}, 4 \mathrm{H}), 2.77(\mathrm{~s}, 4 \mathrm{H}), 1.46$ $(\mathrm{s}, 18 \mathrm{H}) .{ }^{13} \mathrm{C}-\mathrm{NMR}\left(\mathrm{CDCl}_{3}\right) \delta 170.80,82.06,56.63,51.75,48.78,44.66,28.14$.

\subsection{Ethyl 2-(3-hydroxy-2-oxopyridin-1(2H)-yl)acetate (8)}

The mixture of 3,2-hydroxypridinone $(5.5 \mathrm{~g}, 50 \mathrm{mmol})$ and tert-butyl-bromoacetate $(25 \mathrm{~mL})$ was heated at $140{ }^{\circ} \mathrm{C}$ for 3 days. After cooling to room temperature, the solution was filtered and washed with cold $\mathrm{MeOH}$. Recrystallization the solid from ethanol gave 8 as a white solid $(8.4 \mathrm{~g}, 86 \%)$. ${ }^{1} \mathrm{H}-\mathrm{NMR}$ $\left(\mathrm{DMSO}-d_{6}\right) \delta 9.14(\mathrm{~s}, 1 \mathrm{H}), 7.13(\mathrm{dd}, J=6.9,1.6 \mathrm{~Hz}, 1 \mathrm{H}), 6.72(\mathrm{dd}, J=7.3,1.6 \mathrm{~Hz}, 1 \mathrm{H}), 6.11(\mathrm{t}, J=7.1 \mathrm{~Hz}$, 1H), $4.71(\mathrm{~s}, 2 \mathrm{H}), 4.13$ (q, $J=7.1 \mathrm{~Hz}, 2 \mathrm{H}), 1.30-1.07(\mathrm{~m}, 3 \mathrm{H}) .{ }^{13} \mathrm{C}-\mathrm{NMR}$ (DMSO-d6) $\delta$ 168.48, 158.35, $147.12,129.31,115.81,105.67,61.39,50.76,14.46$.

\subsection{Ethyl 2-(3-(benzyloxy)-2-oxopyridin-1(2H)-yl)acetate (9a)}

To a solution of $8(1.0 \mathrm{~g}, 5.1 \mathrm{mmol})$ in $\mathrm{MeCN}$ was added $\mathrm{BnCl}(1.3 \mathrm{~g}, 10 \mathrm{mmol})$ and $\mathrm{K}_{2} \mathrm{CO}_{3}(1.4 \mathrm{~g}$, $10 \mathrm{mmol}$ ), and the reaction mixture was heated at $50{ }^{\circ} \mathrm{C}$ for $4 \mathrm{~h}$. The reaction mixture was filtered and evaporated. The residue was purified by silica column chromatography (ethyl acetate-hexane, 1:3) to obtain 9a $(1.2 \mathrm{~g}, 84 \%)$ as a white solid. ${ }^{1} \mathrm{H}-\mathrm{NMR}\left(\mathrm{CDCl}_{3}\right) \delta 7.41(\mathrm{~d}, J=7.4 \mathrm{~Hz}, 2 \mathrm{H}), 7.34(\mathrm{t}, J=7.3 \mathrm{~Hz}$, 2H), $7.29(\mathrm{~d}, J=7.2 \mathrm{~Hz}, 1 \mathrm{H}), 6.85(\mathrm{dd}, J=6.9,1.6 \mathrm{~Hz}, 1 \mathrm{H}), 6.66(\mathrm{dd}, J=7.4,1.5 \mathrm{~Hz}, 1 \mathrm{H}), 6.04$ (t, $J=7.2 \mathrm{~Hz}, 1 \mathrm{H}), 5.09$ (s, 2H), $4.65(\mathrm{~s}, 2 \mathrm{H}), 4.22(\mathrm{q}, J=7.1 \mathrm{~Hz}, 2 \mathrm{H}), 1.37-1.19(\mathrm{~m}, 3 \mathrm{H}) .{ }^{13} \mathrm{C}-\mathrm{NMR}$ $\left(\mathrm{CDCl}_{3}\right) \delta 167.69,158.19,148.81,136.19,129.36,128.53,127.97,127.33,116.03,104.92,70.74$, $61.79,50.48,14.10$.

\subsection{2-(3-(Benzyloxy)-2-oxopyridin-1(2H)-yl)acetic acid $\mathbf{( 9 b )}$}

Compound 8 (4.6 g, $23 \mathrm{mmol}$ ) was dissolved in methanol-water $(9: 1,150 \mathrm{~mL})$. To this solution $\mathrm{BnCl}$ $(11.8 \mathrm{~g}, 93.2 \mathrm{mmol})$ and $\mathrm{NaOH}(2.8 \mathrm{~g}, 70 \mathrm{mmol})$ were added, and the mixture was heated to reflux for $6 \mathrm{~h}$. The methanol was removed by evaporation and the aqueous solution was extracted with dichloromethane to remove excess benzyl chloride. The aqueous phase is diluted slightly by adding extra water and then acidified to $\mathrm{pH} 2$ using concentrated hydrochloric acid, which results in the precipitation of a beige solid. The precipitate filtered off and washed with diethyl ether. The crude product was recrystallized 
from ethanol to give $9 \mathbf{b}(5.7 \mathrm{~g}, 95 \%)$ as a white solid. ${ }^{1} \mathrm{H}-\mathrm{NMR}$ (DMSO- $\left.d 6\right) \delta 7.46-7.30(\mathrm{~m}, 5 \mathrm{H}), 7.25$ (dd, $J=6.9,1.6 \mathrm{~Hz}, 1 \mathrm{H}), 6.92(\mathrm{dd}, J=7.5,1.5 \mathrm{~Hz}, 1 \mathrm{H}), 6.13(\mathrm{t}, J=7.1 \mathrm{~Hz}, 1 \mathrm{H}), 5.00(\mathrm{~s}, 2 \mathrm{H}), 4.62$ (s, 2H). ${ }^{13} \mathrm{C}-\mathrm{NMR}$ (DMSO- $d_{6}$ ) $\delta 169.87,157.54,148.36,136.96,131.20,128.86,128.41,128.39,116.19$, $104.24,70.23,50.66$.

\subsection{3-(Benzyloxy)-1-(2-hydroxyethyl)pyridin-2(1H)-one (10)}

To a solution of acid 9a $(200 \mathrm{mg}, 0.696 \mathrm{mmol})$ in dry THF $(5 \mathrm{~mL})$ under $\mathrm{N}_{2}$ was added $\mathrm{BH}_{3} \cdot \mathrm{THF}$ $(1.0 \mathrm{M}, 1.4 \mathrm{~mL}, 1.4 \mathrm{mmol})$, and the reaction mixture was stirred at room temperature for $5 \mathrm{~h}$. The reaction mixture was poured over crushed ice, extracted with dichloromethane, dried $\left(\mathrm{MgSO}_{4}\right)$, and filtered, and the solvents were removed in vacuo to give $\mathbf{1 0}(136 \mathrm{mg}, 80.0 \%)$ as a colorless oil which was used in the next step without purification. ${ }^{1} \mathrm{H}-\mathrm{NMR}\left(\mathrm{CDCl}_{3}\right) \delta 7.38(\mathrm{~d}, J=7.0 \mathrm{~Hz}, 2 \mathrm{H}), 7.34-7.28$ (m, 2H), 7.28-7.22 (m, 1H), $6.93(\mathrm{dd}, J=6.9,1.6 \mathrm{~Hz}, 1 \mathrm{H}), 6.64(\mathrm{dd}, J=7.5,1.5 \mathrm{~Hz}, 1 \mathrm{H}), 6.00(\mathrm{t}, J=7.2 \mathrm{~Hz}$, $1 \mathrm{H}), 5.03(\mathrm{~s}, 2 \mathrm{H}), 4.07(\mathrm{t}, J=4.7 \mathrm{~Hz}, 2 \mathrm{H}), 3.88-3.82(\mathrm{~m}, 2 \mathrm{H}), 2.29(\mathrm{~s}, 1 \mathrm{H}) .{ }^{13} \mathrm{C}-\mathrm{NMR}\left(\mathrm{CDCl}_{3}\right) \delta$ $158.99,148.73,136.09,130.05,128.59,128.07,127.38,116.01,105.07,70.77,61.39,53.21$.

\subsection{3-(Benzyloxy)-1-(2-hydroxyethyl)pyridin-2(1H)-one (10)}

To a solution of acid $9 \mathbf{b}(5.8 \mathrm{~g}, 22 \mathrm{mmol})$ in dry THF $(20 \mathrm{~mL})$ under $\mathrm{N}_{2}$ was added $\mathrm{BH}_{3} \cdot \mathrm{THF}(1.0 \mathrm{M}$, $44.5 \mathrm{mmol}$ ), and the reaction mixture was stirred at room temperature for $5 \mathrm{~h}$. The reaction mixture was poured over crushed ice, extracted with dichloromethane, dried $\left(\mathrm{MgSO}_{4}\right)$, and filtered, and the solvents were removed in vacuo to give $\mathbf{1 0}(2.2 \mathrm{~g}, 90 \%)$ as a colorless oil which was used in the next step without purification.

\subsection{3-(Benzyloxy)-1-(2-chloroethyl)pyridin-2(1H)-one (4)}

To a solution of $\mathbf{1 0}(2.5 \mathrm{~g}, 10 \mathrm{mmol})$ and TEA $(3.0 \mathrm{~g}, 30 \mathrm{mmol})$ in dry $\mathrm{CHCl}_{3}(30 \mathrm{~mL})$ was added $\mathrm{MsCl}(1.4 \mathrm{~g}, 12 \mathrm{mmol})$ in $\mathrm{CHCl}_{3}(20 \mathrm{~mL})$ dropwise at $0{ }^{\circ} \mathrm{C}$. The reaction mixture was allowed to warm to room temperature and stirred overnight. The reaction mixture was evaporated and passed a short silica column (ethyl acetate/hexane, 1:5) to give $4(1.9 \mathrm{~g}, 72 \%)$ as a white solid. ${ }^{1} \mathrm{H}-\mathrm{NMR}\left(\mathrm{CDCl}_{3}\right) \delta 7.43(\mathrm{~d}$, $J=7.3 \mathrm{~Hz}, 2 \mathrm{H}), 7.39-7.33(\mathrm{~m}, 2 \mathrm{H}), 7.33-7.26(\mathrm{~m}, 1 \mathrm{H}), 6.96(\mathrm{dd}, J=6.9,1.6 \mathrm{~Hz}, 1 \mathrm{H}), 6.68(\mathrm{dd}$, $J=7.5,1.6 \mathrm{~Hz}, 1 \mathrm{H}), 6.04(\mathrm{t}, J=7.2 \mathrm{~Hz}, 1 \mathrm{H}), 5.11(\mathrm{~s}, 2 \mathrm{H}), 4.25(\mathrm{dd}, J=7.0,4.3 \mathrm{~Hz}, 2 \mathrm{H}), 3.91(\mathrm{dd}$, $J=7.0,4.3 \mathrm{~Hz}, 2 \mathrm{H}) .{ }^{13} \mathrm{C}-\mathrm{NMR}\left(\mathrm{CDCl}_{3}\right) \delta 158.03,148.83,136.13,130.18,128.59,128.04,127.33$, 115.78, 104.37, 70.77, 52.21, 41.91 .

3.9. tert-Butyl-2,2'-(7-(2-(3-(benzyloxy)-2-oxopyridin-1(2H)-yl)ethyl)-1,4,7-triazonane-1,4-diyl) diacetate (11)

To a solution of $\mathbf{3}(357 \mathrm{mg}, 1.00 \mathrm{mmol})$ in acetonitrile $(20 \mathrm{~mL})$ was dropwise added DIEA (387 $\mathrm{mg}$, $3.00 \mathrm{mmol})$ and $4(316.0 \mathrm{mg}, 1.2 \mathrm{mmol})$ in acetonitrile $(10 \mathrm{~mL})$. The reaction mixture was stirred at room temperature $\left(23{ }^{\circ} \mathrm{C}\right)$ for $1 \mathrm{~d}$. After evaporation of the solvent, the residue was purified via silica column chromatography $\left(\mathrm{CH}_{2} \mathrm{Cl}_{2}-\mathrm{MeOH}, 20: 1\right)$ to obtain 11 (364 mg, 62.2\%) as a yellow oil. ${ }^{1} \mathrm{H}-\mathrm{NMR}$ $\left(\mathrm{CDCl}_{3}\right) \delta 7.56-7.47(\mathrm{~m}, 1 \mathrm{H}), 7.44-7.20(\mathrm{~m}, 5 \mathrm{H}), 6.67(\mathrm{~d}, J=7.5 \mathrm{~Hz}, 1 \mathrm{H}), 6.08(\mathrm{t}, J=7.2 \mathrm{~Hz}, 1 \mathrm{H})$, $5.02(\mathrm{~s}, 2 \mathrm{H}), 4.51-4.39(\mathrm{~m}, 2 \mathrm{H}), 3.50(\mathrm{~d}, J=9.1 \mathrm{~Hz}, 7 \mathrm{H}), 3.36(\mathrm{~d}, J=5.6 \mathrm{~Hz}, 2 \mathrm{H}), 3.22(\mathrm{~d}, J=14.3 \mathrm{~Hz}$, 
2H), 3.12-2.85 (m, 4H), $2.74(\mathrm{t}, J=20.2 \mathrm{~Hz}, 2 \mathrm{H}), 1.40(\mathrm{~s}, 18 \mathrm{H}) .{ }^{13} \mathrm{C}-\mathrm{NMR}\left(\mathrm{CDCl}_{3}\right) \delta 169.99,158.18$, $148.49,135.94,129.99,128.58,128.10,127.41,115.94,105.63,82.26,70.74,56.45,52.77,51.60$, 50.71, 48.79, 45.46, 28.13. MALDI-HRMS (matrix: HCCA) Calculated for $\mathrm{C}_{32} \mathrm{H}_{48} \mathrm{~N}_{4} \mathrm{O}_{6}:[\mathrm{M}+\mathrm{H}]^{+} \mathrm{m} / z$ 585.3607, Found 585.3636.

\subsection{2,2'-(7-(2-(3-Hydroxy-2-oxopyridin-1(2H)-yl)ethyl)-1,4,7-triazonane-1,4-diyl)diacetic acid (HE-NO2A, 1)}

Compound $11(100 \mathrm{mg}, 0.171 \mathrm{mmol})$ at $0{ }^{\circ} \mathrm{C}$ in $2 \mathrm{~mL}$ acetic acid was added dropwise with $37 \% \mathrm{HBr}$ in acetic acid $(5 \mathrm{~mL})$. The resulting mixture was allowed to warm at room temperature and stirred for 2 days. The solvent was evaporated in vacuo, the residue was taken up in DI water and passed through a $0.45 \mu \mathrm{m}$ nylon syringe filter. The aqueous solution was concentrated in vacuo to provide HE-NO2A $(60 \mathrm{mg}, 91 \%)$ as a yellow solid. ${ }^{1} \mathrm{H}-\mathrm{NMR}\left(\mathrm{D}_{2} \mathrm{O}\right) \delta 7.17(\mathrm{dd}, J=6.9,1.6 \mathrm{~Hz}, 1 \mathrm{H}), 7.01(\mathrm{dd}, J=7.6$, $1.5 \mathrm{~Hz}, 1 \mathrm{H}), 6.47-6.37(\mathrm{~m}, 1 \mathrm{H}), 4.46-4.39(\mathrm{~m}, 2 \mathrm{H}), 3.91(\mathrm{~s}, 4 \mathrm{H}), 3.75-3.69$ (m, 2H), $3.61(\mathrm{~s}, 4 \mathrm{H}), 3.45$ (t, $J=5.6 \mathrm{~Hz}, 4 \mathrm{H}), 3.35(\mathrm{~s}, 4 \mathrm{H}) .{ }^{13} \mathrm{C}-\mathrm{NMR}\left(\mathrm{D}_{2} \mathrm{O}\right) \delta 171.99,159.43,145.64,129.38,119.55,109.78$, 57.30, 56.77, 51.14, 50.64, 49.52, 47.14. MALDI-HRMS (matrix: HCCA) Calculated for $\mathrm{C}_{17} \mathrm{H}_{26} \mathrm{~N}_{4} \mathrm{O}_{6}$ : $[\mathrm{M}+\mathrm{H}]^{+} m / z$ 383.1886. Found: 383.1936 .

\subsection{Methyl 3-(3-Hydroxy-2-oxopyridin-1(2H)-yl)propanoate (12)}

To a solution of 7 (5.5 g $50 \mathrm{mmol})$ in methyl acrylate $(25 \mathrm{~mL})$ was added CsF $(0.5 \mathrm{~g})$, and the reaction mixture was heated at reflux for 2 days. The excess methyl acrylate was removed in vacuo. The residue was resolved in hot $\mathrm{MeCN}$, and filtered. The filtratate was evaporated to give the crude, which was recrystallized from ethanol gave 12 as a white solid $(8.5 \mathrm{~g}, 87 \%) .{ }^{1} \mathrm{H}-\mathrm{NMR}$ (DMSO-d6) $\delta 9.04$ (s, $1 \mathrm{H}), 7.12(\mathrm{dd}, J=6.8,1.5 \mathrm{~Hz}, 1 \mathrm{H}), 6.69(\mathrm{dd}, J=7.2,1.5 \mathrm{~Hz}, 1 \mathrm{H}), 6.08(\mathrm{t}, J=7.0 \mathrm{~Hz}, 1 \mathrm{H}), 4.13$ (t, $J=7.0 \mathrm{~Hz}, 2 \mathrm{H}), 3.59(\mathrm{~s}, 3 \mathrm{H}), 2.76(\mathrm{t}, J=6.9 \mathrm{~Hz}, 2 \mathrm{H}) .{ }^{13} \mathrm{C}-\mathrm{NMR}$ (DMSO-d6) $\delta 171.64,158.13,147.11$, $128.85,115.22,105.69,51.97,45.66,33.10$.

\subsection{Methyl 3-(3-(Benzyloxy)-2-oxopyridin-1(2H)-yl)propanoate (13a)}

To a solution of $12(0.8 \mathrm{~g} 4 \mathrm{mmol})$ in $\mathrm{MeCN}$ was added $\mathrm{BnCl}(1.0 \mathrm{~g}, 7.9 \mathrm{mmol}) \mathrm{K}_{2} \mathrm{CO}_{3}(1.1 \mathrm{~g}$, $8.0 \mathrm{mmol}$ ), and the reaction mixture was heated at $50{ }^{\circ} \mathrm{C}$ for $4 \mathrm{~h}$. The reaction mixture was filtered and evaporated. The residue was purified by silica column chromatography (ethyl acetate-hexane, 1:3) to obtain 13a $(0.9 \mathrm{~g}, 74 \%)$ as a white solid. ${ }^{1} \mathrm{H}-\mathrm{NMR}\left(\mathrm{CDCl}_{3}\right) \delta 7.41(\mathrm{~d}, J=7.1 \mathrm{~Hz}, 2 \mathrm{H}), 7.34(\mathrm{dd}, J=11.4$, $4.4 \mathrm{~Hz}, 2 \mathrm{H}), 7.31-7.26(\mathrm{~m}, 1 \mathrm{H}), 7.03(\mathrm{dd}, J=6.9,1.5 \mathrm{~Hz}, 1 \mathrm{H}), 6.64(\mathrm{dd}, J=7.4,1.5 \mathrm{~Hz}, 1 \mathrm{H}), 6.00$ (t, $J=7.2 \mathrm{~Hz}, 1 \mathrm{H}), 5.08(\mathrm{~s}, 2 \mathrm{H}), 4.20(\mathrm{t}, J=6.4 \mathrm{~Hz}, 2 \mathrm{H}), 3.64(\mathrm{~s}, 3 \mathrm{H}), 2.86(\mathrm{t}, J=6.4 \mathrm{~Hz}, 2 \mathrm{H}) .{ }^{13} \mathrm{C}-\mathrm{NMR}$ $\left(\mathrm{CDCl}_{3}\right) \delta 171.99,158.06,148.76,136.21,129.99,128.54,127.98,127.31,115.61,104.53,70.70$, $51.85,46.32,32.72$.

\subsection{3-(3-(Benzyloxy)-2-oxopyridin-1(2H)-yl)propanoic acid (13b)}

Compound 12 (3.8 g $19 \mathrm{mmol})$ was dissolved in methanol/water $(9: 1,70 \mathrm{~mL})$. To this solution $\mathrm{BnCl}$ $(9.8 \mathrm{~g}, 77 \mathrm{mmol})$ and $\mathrm{NaOH}(2.4 \mathrm{~g}, 60 \mathrm{mmol})$ was added, and the mixture was heated to reflux for $6 \mathrm{~h}$. The methanol was removed by evaporation and the aqueous solution was extracted with 
dichloromethane to remove excess benzyl chloride. The aqueous phase is diluted slightly by adding extra water and then acidified to $\mathrm{pH} 2$ using concentrated hydrochloric acid, which resulted in the precipitation of a beige solid. The precipitate filtered off and washed with diethyl ether. The crude product was recrystallized from ethanol to give $\mathbf{1 3 b}\left(5.1 \mathrm{~g}, 97 \%\right.$ ) as a white solid. ${ }^{1} \mathrm{H}-\mathrm{NMR}$ (DMSO- $d_{6}$ ) $\delta 7.37(\mathrm{~m}, 5 \mathrm{H}), 7.25$ (d, $J=6.2 \mathrm{~Hz}, 1 \mathrm{H}), 6.88(\mathrm{~d}, J=7.1 \mathrm{~Hz}, 1 \mathrm{H}), 6.10$ (t, $J=7.1 \mathrm{~Hz}, 1 \mathrm{H}), 4.99$ (s, $2 \mathrm{H}), 4.06(\mathrm{t}, J=6.9 \mathrm{~Hz}, 2 \mathrm{H}), 2.65(\mathrm{t}, J=6.9 \mathrm{~Hz}, 2 \mathrm{H}) .{ }^{13} \mathrm{C}-\mathrm{NMR}$ (DMSO-d 6 ) $\delta 172.76,157.30,148.35$, $137.00,130.89,128.85,128.41,128.38,115.93,104.29,70.21,45.81,33.29$.

\subsection{3-(Benzyloxy)-1-(3-hydroxypropyl)pyridin-2(1H)-one (14)}

To a solution of acid 13a $(2.6 \mathrm{~g}, 10 \mathrm{mmol})$ in dry THF $(15 \mathrm{~mL})$ under $\mathrm{N}_{2}$ was added $\mathrm{BH}_{3} \cdot \mathrm{THF}(1 \mathrm{M}$, $20 \mathrm{~mL}$ ), and the reaction mixture was stirred at room temperature for $5 \mathrm{~h}$. The reaction mixture was poured over crushed ice, extracted with dichloromethane, dried $\left(\mathrm{MgSO}_{4}\right)$, and filtered, and the solvents were removed in vacuo to give $14(1.5 \mathrm{~g}, 67 \%)$ as a colorless oil which was used in the next step without purification. ${ }^{1} \mathrm{H}-\mathrm{NMR}\left(\mathrm{CDCl}_{3}\right) \delta 7.40(\mathrm{~d}, J=7.3 \mathrm{~Hz}, 2 \mathrm{H}), 7.33(\mathrm{t}, J=7.2 \mathrm{~Hz}, 2 \mathrm{H}), 7.30-7.26$ $(\mathrm{m}, 1 \mathrm{H}), 6.92(\mathrm{dd}, J=6.9,1.6 \mathrm{~Hz}, 1 \mathrm{H}), 6.68(\mathrm{dd}, J=7.5,1.4 \mathrm{~Hz}, 1 \mathrm{H}), 6.10(\mathrm{t}, J=7.1 \mathrm{~Hz}, 1 \mathrm{H}), 5.09$ (s, 2H), 4.24-4.07 (m, 2H), $3.49(\mathrm{t}, J=5.5 \mathrm{~Hz}, 2 \mathrm{H}), 1.95-1.82(\mathrm{~m}, 2 \mathrm{H}) .{ }^{13} \mathrm{C}-\mathrm{NMR}\left(\mathrm{CDCl}_{3}\right) \delta 158.94$, $148.56,136.02,128.83,128.61,128.08,127.37,115.96,105.97,70.80,57.59,45.82,32.33$.

\subsection{3-(Benzyloxy)-1-(3-hydroxypropyl)pyridin-2(1H)-one (14)}

To a solution of acid $\mathbf{1 3 b}(2.7 \mathrm{~g} .10 \mathrm{mmol})$ in dry THF $(20 \mathrm{~mL})$ under $\mathrm{N}_{2}$ was added $\mathrm{BH}_{3} \cdot \mathrm{THF}(1.0 \mathrm{M}$, $20 \mathrm{~mL}, 20 \mathrm{mmol}$ ), and the reaction mixture was stirred at room temperature for $5 \mathrm{~h}$. The reaction mixture was poured over crushed ice, extracted with dichloromethane, dried $\left(\mathrm{MgSO}_{4}\right)$, and filtered, and the solvents were removed in vacuo to give $14(2.1 \mathrm{~g}, 81 \%)$ as a colorless oil which was used in the next step without purification.

\subsection{9-(Benzyloxy)-3,4-dihydro-2H-pyrido[2,1-b][1,3]oxazin-5-ium methanesulfonate (15)}

To a solution of $14(2.6 \mathrm{~g}, 10 \mathrm{mmol})$ and TEA $(3.0 \mathrm{~g}, 30 \mathrm{mmol})$ in dry $\mathrm{CHCl}_{3}(30 \mathrm{~mL})$ was added dropwise $\mathrm{MsCl}(1.4 \mathrm{~g}, 12 \mathrm{mmol})$ in $\mathrm{CHCl}_{3}(20 \mathrm{~mL})$ at $0{ }^{\circ} \mathrm{C}$. The reaction mixture was allowed to warm to room temperature and stirred overnight. The reaction mixture was stirred overnight, diluted with $\mathrm{CHCl}_{3}$, and washed with $5 \% \mathrm{NaHCO}_{3}(3 \times 50 \mathrm{~mL})$ and brine $(1 \times 50 \mathrm{~mL})$. The organic solution was dried over $\mathrm{Na}_{2} \mathrm{SO}_{4}$ and evaporated in vacuo. Ethyl acetate (EA) was added to the residue, which resulted in the precipitation of a white solid. The precipitate filtered off and washed with EA to obtain $15(2.7 \mathrm{~g}, 80 \%)$ as a white solid. ${ }^{1} \mathrm{H}-\mathrm{NMR}\left(\mathrm{CDCl}_{3}\right) \delta 8.12(\mathrm{~d}, J=6.2 \mathrm{~Hz}, 1 \mathrm{H}), 7.69-7.63(\mathrm{~m}, 1 \mathrm{H}), 7.35$ (dt, $J=8.7,7.2 \mathrm{~Hz}, 5 \mathrm{H}), 7.28-7.21(\mathrm{~m}, 1 \mathrm{H}), 5.18(\mathrm{~s}, 2 \mathrm{H}), 4.85(\mathrm{dt}, J=28.7,5.5 \mathrm{~Hz}, 4 \mathrm{H}), 2.60$ (d, $J=2.0 \mathrm{~Hz}, 3 \mathrm{H}), 2.52-2.37(\mathrm{~m}, 2 \mathrm{H}) .{ }^{13} \mathrm{C}-\mathrm{NMR}\left(\mathrm{CDCl}_{3}\right) \delta 161.49,151.73,146.13,134.26,132.53$, $128.87,127.80,124.58,117.84,72.16,68.71,50.59,39.51,19.99$. 
3.17. tert-Butyl-2,2'-(7-(3-(3-(benzyloxy)-2-oxopyridin-1(2H)-yl)propyl)-1,4,7-triazonane-1,4-diyl) diacetate (16)

To a solution of $3(357 \mathrm{mg}, 1.00 \mathrm{mmol})$ in acetonitrile was dropwise added DIEA (387 mg, $3.00 \mathrm{mmol})$ and $15(400.0 \mathrm{mg}, 1.2 \mathrm{mmol})$ in acetonitrile $(10 \mathrm{~mL})$. The reaction mixture was stirred at room temperature for 1 day. After evaporation of the solvent, the residue was purified via silica column chromatography $\left(\mathrm{CH}_{2} \mathrm{Cl}_{2}-\mathrm{MeOH}, 20: 1\right)$ to obtain $16(317.0 \mathrm{mg}, 53 \%)$ as a yellow oil. ${ }^{1} \mathrm{H}-\mathrm{NMR}\left(\mathrm{CDCl}_{3}\right) \delta 7.44-7.20$ $(\mathrm{m}, 6 \mathrm{H}), 6.67(\mathrm{~d}, J=7.4 \mathrm{~Hz}, 1 \mathrm{H}), 6.08(\mathrm{t}, J=7.1 \mathrm{~Hz}, 1 \mathrm{H}), 5.06(\mathrm{~s}, 2 \mathrm{H}), 4.47(\mathrm{~d}, J=6.6 \mathrm{~Hz}, 2 \mathrm{H}), 3.54$ (s, 3H), 3.47 (s, 4H), $3.38(\mathrm{~d}, J=25.6 \mathrm{~Hz}, 2 \mathrm{H}), 3.24(\mathrm{~d}, J=45.7 \mathrm{~Hz}, 4 \mathrm{H}), 2.78(\mathrm{~d}, J=24.1 \mathrm{~Hz}, 4 \mathrm{H})$, $1.43(\mathrm{~s}, 18 \mathrm{H}), 1.26(\mathrm{dd}, J=16.3,8.6 \mathrm{~Hz}, 2 \mathrm{H}) .{ }^{13} \mathrm{C}-\mathrm{NMR}\left(\mathrm{CDCl}_{3}\right) \delta 170.44,158.19,148.57,136.00$, 129.91, 128.57, 128.07, 127.33, 116.00, 105.53, 81.68, 70.76, 58.46, 54.15, 53.23, 52.57, 51.62, 45.49, 29.64, 28.13. MALDI-HRMS (matrix: HCCA) Calculated for $\mathrm{C}_{33} \mathrm{H}_{50} \mathrm{~N}_{4} \mathrm{O}_{6}:[\mathrm{M}+\mathrm{H}]^{+} \mathrm{m} / z$ 599.3764, Found 599.3792.

\subsection{2,2'-(7-(3-(3-Hydroxy-2-oxopyridin-1(2H)-yl)propyl)-1,4,7-triazonane-1,4-diyl)diacetic acid} (HP-NO2A, 2)

Compound $16(150 \mathrm{mg}, 0.251 \mathrm{mmol})$ at $0{ }^{\circ} \mathrm{C}$ in $2 \mathrm{~mL}$ acetic acid was added dropwise with $37 \%$ $\mathrm{HBr}$ in acetic acid $(5 \mathrm{~mL})$. The resulting mixture was allowed to warm to room temperature and stirred for 2 days. The solvent was evaporated in vacuo, the residue was taken up in DI water and passed through a $0.45 \mu \mathrm{m}$ nylon syringe filter. The aqueous solution was concentrated in vacuo to provide 2 ( $89 \mathrm{mg}$, $90 \%)$ as a yellow solid. ${ }^{1} \mathrm{H}-\mathrm{NMR}\left(\mathrm{D}_{2} \mathrm{O}\right) \delta 7.20(\mathrm{dd}, J=6.8,1.5 \mathrm{~Hz}, 1 \mathrm{H}), 7.02(\mathrm{dd}, J=7.6,1.6 \mathrm{~Hz}, 1 \mathrm{H})$, 6.47-6.40 (m, 1H), 4.17-4.07 (m, 2H), 3.95 (s, 3H), 3.99-3.84 (m, 4H), 3.63-3.54 (m, 5H), 3.46 (s, $4 \mathrm{H}), 3.41-3.30(\mathrm{~m}, 6 \mathrm{H}), 2.40-2.20(\mathrm{~m}, 2 \mathrm{H}) .{ }^{13} \mathrm{C}-\mathrm{NMR}\left(\mathrm{D}_{2} \mathrm{O}\right) \delta 172.28,158.73,145.45,129.09$, 119.66, 109.64, 57.46, 57.07, 54.00, 51.27, 50.17, 49.22, 46.31, 24.09. MALDI-HRMS (matrix: $\mathrm{HCCA}$ ) Calculated for $\mathrm{C}_{18} \mathrm{H}_{28} \mathrm{~N}_{4} \mathrm{O}_{6}:[\mathrm{M}+\mathrm{H}]^{+} m / z$ 397.2042. Found 397.2076.

\section{Acknowledgments}

This study was partially supported by Natural Science Foundation of Hubei Province, China (2012FFB02418), Specialized Research Fund for the Doctoral Program of Higher Education of China (20120142120095), Independent Innovation Foundation of HUST (2014TS090).

\section{Author Contributions}

X.M. and G.X. designed the research and wrote the paper; Y.G. and Z.H. synthesized the compounds; Z.R. recorded and analyzed the NMR spectra. All authors read and approved the final manuscript.

\section{Conflicts of Interest}

The authors declare no conflict of interest. 


\section{Reference}

1. Burke, B.P.; Archibald, S.J. Macrocyclic coordination chemistry. Annu. Rep. Prog. Chem. Sect. A: Inorg. Chem. 2013, 109, 232-253.

2. Caravan, P.; Ellison, J.J.; McMurry, T.J.; Lauffer, R.B. Gadolinium(III) chelates as mri contrast agents: Structure, dynamics, and applications. Chem. Rev. 1999, 99, 2293-2352.

3. Pandya, D.N.; Bhatt, N.; An, G.I.; Ha, Y.S.; Soni, N.; Lee, H.; Lee, Y.J.; Kim, J.Y.; Lee, W.; Ahn, H.; et al. Propylene cross-bridged macrocyclic bifunctional chelator: A new design for facile bioconjugation and robust 64cu complex stability. J. Med. Chem. 2014, 57, 7234-7243.

4. Notni, J.; Šimeček, J.; Wester, H.-J. Phosphinic acid functionalized polyazacycloalkane chelators for radiodiagnostics and radiotherapeutics: Unique characteristics and applications. ChemMedChem 2014, 9, 1107-1115.

5. Peterson, K.L.; Dang, J.V.; Weitz, E.A.; Lewandowski, C.; Pierre, V.C. Effect of lanthanide complex structure on cell viability and association. Inorg. Chem. 2014, 53, 6013-6021.

6. Kharisov, B.I.; Kharissova, O.V.; Berdonosov, S.S. Radioactive nanoparticles and their main applications: Recent advances. Recent Pat. Nanotechnol. 2014, 8, 79-96.

7. Comby, S.; Surender, E.M.; Kotova, O.; Truman, L.K.; Molloy, J.K.; Gunnlaugsson, T. Lanthanide-functionalized nanoparticles as mri and luminescent probes for sensing and/or imaging applications. Inorg. Chem. 2014, 53, 1867-1879.

8. Huang, H.; Zhang, P.; Yu, B.; Chen, Y.; Wang, J.; Ji, L.; Chao, H. Targeting nucleus DNA with a cyclometalated dipyridophenazineruthenium (II) complex. J. Med. Chem. 2014, 57, 8971-8983.

9. Adams, N.; Arts, H.J.; Bolton, P.D.; Cowell, D.; Dubberley, S.R.; Friederichs, N.; Grant, C.M.; Kranenburg, M.; Sealey, A.J.; Wang, B.; et al. Imido titanium ethylene polymerization catalysts containing triazacyclic ligands. Organometallics 2006, 25, 3888-3903.

10. Tfouni, E.; Doro, F.G.; Figueiredo, L.E.; Pereira, J.C.M.; Metzker, G.; Franco, D.W. Tailoring no donors metallopharmaceuticals: Ruthenium nitrosyl ammines and aliphatic tetraazamacrocycles. Curr. Med. Chem. 2010, 17, 3643-3657.

11. Ballesteros, P.; Soriano, E.; Perez-Mayoral, E.; Garcia-Amo, M.; Cerdan, S. Flexible Tetraazamacrocycles as Metal Ligands. Their Relevance in Magnetic Resonance Imaging; Research Signpost: Trivandrum, India, 2005; pp. 69-86.

12. Haines, R.I. Pendant-arm tri- and tetraazamacrocycles: Synthesis, structure and properties of their first-row transition metal complexes. Rev. Inorg. Chem. 2001, 21, 165-205.

13. Meyer, M.; Dahaoui-Gindrey, V.; Lecomte, C.; Guilard, R. Conformations and coordination schemes of carboxylate and carbamoyl derivatives of the tetraazamacrocycles cyclen and cyclam, and the relation to their protonation states. Coord. Chem. Rev. 1998, 178-180, 1313-1405.

14. Warden, A.; Graham, B.; Hearn, M.T.W.; Spiccia, L. Synthesis of novel derivatives of 1,4,7-triazacyclononane. Org. Lett. 2001, 3, 2855-2858.

15. Warden, A.C.; Spiccia, L.; Hearn, M.T.W.; Boas, J.F.; Pilbrow, J.R. The synthesis, structure and properties of copper(II) complexes of asymmetrically functionalized derivatives of 1,4,7-triazacyclononane. Dalton Trans. 2005, doi:10.1039/B417739H. 
16. Schulz, D.; Weyhermüller, T.; Wieghardt, K.; Butzlaff, C.; Trautwein, A.X. A structural and magnetochemical study of some copper(ii) complexes containing the ligands 1,4,7-triazacyclononane$n$-acetate $\left(\mathrm{L}^{1}\right)$ and $N$-(2-hydroxybenzyl)-1,4,7-triazacyclononane $\left(\mathrm{HL}^{2}\right)$. Inorg. Chim. Acta. 1996, 246, 387-394.

17. Malkhasian, A.Y.S.; Finch, M.E.; Nikolovski, B.; Menon, A.; Kucera, B.E.; Chavez, F.A. $N, N^{\prime}$-dimethylformamide-derived products from catalytic oxidation of 3-hydroxyflavone. Inorg. Chem. 2007, 46, 2950-2952.

18. Malkhasian, A.; Finch, M.E.; Pawlak, P.L.; Anderson, J.M.; Brennessel, W.W.; Chavez, F.A. Synthesis, structure, and characterization of dichloro-(1-benzyl-4-acetato-1,4,7-triazacyclononane) iron(III). Z. Anorg. Allg. Chem. 2008, 634, 1087-1092.

19. Pawlak, P.L.; Panda, M.; Li, J.; Banerjee, A.; Averill, D.J.; Nikolovski, B.; Shay, B.J.; Brennessel, W.W.; Chavez, F.A. Oxalate oxidase model studies-substrate reactivity. Eur. J. Inorg. Chem. 2015, 2015, 646-655.

20. Chaudhuri, P.; Wieghardt, K. The chemistry of 1,4,7-triazacyclononane and related tridentate macrocyclic compounds. Prog. Inorg. Chem. 1987, 35, 329-436.

21. Schulz, D.; Weyhermüller, T.; Wieghardt, K.; Nuber, B. The monofunctionalized 1,4,7-triazacyclononane derivatives 1,4,7-triazacyclononane- $n$-acetate $\left(\mathrm{L}^{1}\right)$ and $N$-(2-hydroxybenzyl1,4,7-triazacyclononane $\left(\mathrm{HL}^{2}\right)$ and their complexes with vanadium (IV)/(V). Localized and delocalized electronic structures in compounds containing the mixed valent $\left[\mathrm{OV}^{\mathrm{IV}}-\mathrm{O}-\mathrm{V}^{\mathrm{V}} \mathrm{O}\right]^{3+}$ core. Inorg. Chim. Acta 1995, 240, 217-229.

22. Simecek, J.; Zemek, O.; Hermann, P.; Wester, H.J.; Notni, J. A monoreactive bifunctional triazacyclononane phosphinate chelator with high selectivity for gallium-68. ChemMedChem 2012, 7, 1375-1378.

23. Chong, H.-S.; Song, H.A.; Ma, X.; Milenic, D.E.; Brady, E.D.; Lim, S.; Lee, H.; Baidoo, K.; Cheng, D.; Brechbiel, M.W. Novel bimodal bifunctional ligands for radioimmunotherapy and targeted mri. Bioconjugate Chem. 2008, 19, 1439-1447.

24. Chong, H.-S.; Song, H.A.; Birch, N.; Le, T.; Lim, S.; Ma, X. Efficient synthesis and evaluation of bimodal ligand neta. Bioorg. Med. Chem. Lett. 2008, 18, 3436-3439.

25. Kang, C.S.; Chen, Y.; Lee, H.; Liu, D.; Sun, X.; Kweon, J.; Lewis, M.R.; Chong, H.-S. Synthesis and evaluation of a new bifunctional NETA chelate for molecular targeted radiotherapy using ${ }^{90} \mathrm{Y}$ or ${ }^{177}$ Lu. Nucl. Med. Biol. 2015, 42, 242-249.

26. Kang, C.S.; Song, H.A.; Milenic, D.E.; Baidoo, K.E.; Brechbiel, M.W.; Chong, H.-S. Preclinical evaluation of NETA-based bifunctional ligand for radioimmunotherapy applications using ${ }^{212} \mathrm{Bi}$ and ${ }^{213} \mathrm{Bi}$ : Radiolabeling, serum stability, and biodistribution and tumor uptake studies. Nucl. Med. Biol. 2013, 40, 600-605.

27. Chong, H.-S.; Garmestani, K.; Bryant, L.H.; Milenic, D.E.; Overstreet, T.; Birch, N.; Le, T.; Brady, E.D.; Brechbiel, M.W. Synthesis and evaluation of novel macrocyclic and acyclic ligands as contrast enhancement agents for magnetic resonance imaging. J. Med. Chem. 2006, 49, 2055-2062.

28. Gorden, A.E.V.; Xu, J.; Raymond, K.N.; Durbin, P. Rational design of sequestering agents for plutonium and other actinides. Chem. Rev. 2003, 103, 4207-4282. 
29. Bunin, D.I.; Chang, P.Y.; Doppalapudi, R.S.; Riccio, E.S.; An, D.; Jarvis, E.E.; Kullgren, B.; Abergel, R.J. Dose-dependent efficacy and safety toxicology of hydroxypyridinonate actinide decorporation agents in rodents: Towards a safe and effective human dosing regimen. Radiat. Res. 2013, 179, 171-182.

30. Shetty, D.; Choi, S.Y.; Jeong, J.M.; Lee, J.Y.; Hoigebazar, L.; Lee, Y.-S.; Lee, D.S.; Chung, J.-K.; Lee, M.C.; Chung, Y.K. Stable aluminium fluoride chelates with triazacyclononane derivatives proved by X-ray crystallography and ${ }^{18}$ F-labeling study. Chem. Commun. 2011, 47, 9732-9734.

31. Chong, H.S.; Sun, X.; Zhong, Y.; Bober, K.; Lewis, M.R.; Liu, D.; Ruthengael, V.C.; Sin, I.; Kang, C.S. Synthesis and evaluation of an enantiomerically enriched bifunctional chelator for ${ }^{64} \mathrm{Cu}$-based positron emission tomography (PET) imaging. Eur. J. Inorg. Chem. 2014, 2014, 1305-1313.

32. De Sá, A.; Bonnet, C.S.; Geraldes, C.F.G.C.; Tóth, É.; Ferreira, P.M.T.; André, J.P. Thermodynamic stability and relaxation studies of small, triaza-macrocyclic $\mathrm{Mn}(\mathrm{II})$ chelates. Dalton Trans. 2013, 42, 4522-4532.

33. Ambrosi, G.; Dapporto, P.; Formica, M.; Fusi, V.; Giorgi, L.; Guerri, A.; Lucarini, S.; Micheloni, M.; Paoli, P.; Pontellini, R. Macrocyclic ligands bearing two 3-(hydroxy)-2-pyridinone moieties as side-arms. Conformational studies, synthesis, crystal structure, and alkali and alkaline earth complex formation. New J. Chem. 2004, 28, 1359-1367.

34. Lambert, T.N.; Chittamuru, S.; Jacobs, H.K.; Gopalan, A.S. New methodology for the preparation of 3-hydroxy-2-pyridinone (3,2-hopo) chelators-Reaction of amines with a novel electrophilic 3,2-hopo precursor. Tetrahedron Lett. 2002, 43, 7379-7383.

35. Chittamuru, S.; Lambert, T.N.; Martinez, G.; Jacobs, H.K.; Gopalan, A.S. New methodology for the preparation of 3-hydroxy-2-pyridinone (3,2-hopo) chelators and extractants. Part 2: Reactions of alcohols, phenols, and thiols with an electrophilic 3,2-hopo reagent. Tetrahedron Lett. 2007, $48,567-571$.

Sample Availability: Samples of the compounds $\mathbf{1}$ and $\mathbf{2}$ are available from the authors.

(C) 2015 by the authors; licensee MDPI, Basel, Switzerland. This article is an open access article distributed under the terms and conditions of the Creative Commons Attribution license (http://creativecommons.org/licenses/by/4.0/). 